\title{
Microbiological Contamination of Fresh Chicken Meat in the Retail Stores
}

\author{
Karahmet Enver*, Isaković Senita, Operta Sabina, Hamidović Saud, Toroman Almir, \\ Đulančić Nermina, Muhamedagić Samir
}

Faculty of Agriculture and Food Sciences, University of Sarajevo, Sarajevo, Bosnia and Herzegovina

Email: *enverkarahmet@yahoo.com *e.karahmet@ppf.unsa.ba

How to cite this paper: Enver, K., Senita, I., Sabina, O., Saud, H., Almir, T., Nermina, Đ. and Samir, M. (2021) Microbiological Contamination of Fresh Chicken Meat in the Retail Stores. Food and Nutrition Sciences, 12, 64-72.

https://doi.org/10.4236/fns.2021.121006

Received: December 8, 2020

Accepted: January 25, 2021

Published: January 28, 2021

Copyright ( 2021 by author(s) and Scientific Research Publishing Inc. This work is licensed under the Creative Commons Attribution International License (CC BY 4.0).

http://creativecommons.org/licenses/by/4.0/

\section{(c) (i) Open Access}

\begin{abstract}
The aim of this study was to assess the hygienic properties of swabs taken from the arm and coat of workers, work surfaces, refrigerated display cases, trays and packaging materials. As well as the safe properties of samples of fresh chicken meat (wing, drumstick, chest) and chicken internal organs (heart and liver) from two butcheries. One of the goals was to determine whether education on hygienic conditions was carried out, influenced the hygienic condition of swabs and safety samples of fresh chicken meat offal. The results of the analysis showed that on the first day of sampling, the largest number of aerobic mesophilic bacteria were found in the swabs of the arm (butcher A-8.15 $\left.\times 10^{2} \mathrm{CFU} / \mathrm{ml}\right)$, butcher $\left(\mathrm{B}-17.88 \times 10^{2} \mathrm{CFU} / \mathrm{ml}\right)$ and the smallest in the packaging material $\left(0.03 \times 10^{2} \mathrm{CFU} / \mathrm{ml}\right)$. Comparing the results of the first and thirtieth sampling day was a visible decrease in the number of aerobic mesophilic bacteria and Enterobacteriaceae for all examined swabs from both butchers. In the samples of fresh chicken meat, the number of aerobic mesophilic bacteria during the first sampling was the highest in the drumstick samples $\left(4.75 \times 10^{3} \mathrm{CFU} / \mathrm{ml}\right)$ slightly less in the samples of the wing $\left(3.78 \times 10^{3} \mathrm{CFU} / \mathrm{ml}\right)$ in the butcher $\mathrm{A}$, in the same time in the butcher $\mathrm{B}$ was $3.82 \times 10^{3} \mathrm{CFU} / \mathrm{ml}$. Microbiological analyzes samples of the thirtieth day showed that Escherichia coli has been found in both butchers in drumsticks A-0.8 CFU/ml, B butcher $0.4 \mathrm{CFU} / \mathrm{ml}$. and offal butcher A $0.6 \mathrm{CFU} / \mathrm{ml}$, butcher B $0.7 \mathrm{CFU} / \mathrm{ml}$, but less than the first day. It is important to say that education of workers in butcher shops has shown that it can improve good hygiene practices in butcher shops and safety of fresh chicken meat. Education in Good Hygiene Practice has positive impact on safety of fresh chicken meat in examined butcheries.
\end{abstract}

\section{Keywords}

Fresh Chicken Meat, Contamination, Butcher, Swabs, Meat Samples, Microbiological Analysis 


\section{Introduction}

Fresh chicken meat is poultry meat appropriate for human consumption, which has not undergone any operation other than cooling. It is meat that has not hardened due to the cooling process and which must be constantly stored/kept at a temperature of $-2^{\circ} \mathrm{C}$ to $+4^{\circ} \mathrm{C}$ [1]. The short shelf life of fresh chicken meat at refrigerator temperature can also be related to the spoilage microorganisms present in the fresh product.

Cutting-off and further sales of poultry meat is very sensitive process from hygienic and safety aspect, given that it is related with a lot of manual manipulation of the raw poultry meat. Spoilage of fresh meat in most cases the result of the action of microorganisms, and rarely occurs as a result of physical and chemical problems. In both cases the changes intensified in unfavorable conditions of production, storage and transport of food. The initial microflora significantly affects the viability of chicken meat, which indicates the importance of the control of the production process, manipulation and storage. Many studies have shown that the main point in the control of poultry meat continues to contamination by pathogenic bacteria, especially Salmonella spp., Campylobacter spp., Staphylococcus spp., Listeria spp., Followed by Aeromonas spp., Yersinia enterocolitica, Escherichia coli and Clostridium perfringens [2] [3] and [4]. As poultry meat is not consumed raw epidemics occur due to secondary contamination caused during production [5] and [6], points out that poultry microflora is transmitted from primary production to production lines and beyond, by subsequent contamination, mainly caused by human factor.

Food business operators must establish and enforce regular control of good hygiene and sanitary conditions in all stages of production, processing and distribution of food. Preventive procedures of self-control, the application of HACCP, checked through a system of official controls described in detail in the Ordinance on food hygiene [7] and the Regulation on the hygiene of food of animal origin [8] According to the Rulebook on microbiological safety of food [9], it is prescribed that the microorganisms Salmonella spp. Hygienic and sanitary conditions of business with chicken meat are more demanding and more difficult in retail than in wholesale [10] and [11]. The main objectives of this study were to examine the hygienic correctness of swabs taken from equipment and work surfaces, as well as the hygienic correctness of samples of fresh chicken meat and offal, taken from two butchers in the city of Zenica on two occasions during 30 days. Also one of the aims was to verify whether it is conducted training on hygiene affects the hygiene of the swabs and samples of chicken fresh meat and offal.

\section{Material and Methods}

During routine control of butchers in Zenica we choose these two butchers because they sell just parts of fresh chicken meat. That was some kind of limitation factor in this study. In order to assess the microbiological risk that exists in the 
sale of fresh chicken meat, swabs were taken during work from the hands of workers, from work surfaces that come into contact with meat, from trays for keeping fresh chicken meat in bulk, from the inner surfaces of refrigerated display cases for storing fresh chicken meat and packaging material (plastic bags) of chicken meat in two butchers (A and B) in the city of Zenica. In addition to taking swabs, samples of chicken meat (wings, drumstick, chest) and offal (heart and liver) were taken for microbiological analysis. The material was delivered to the microbiological laboratory at the Faculty of Agriculture and Food Sciences, University of Sarajevo; microbiological analyzes were performed. The results were calculated as the mean of the three measurements.

Swabs (in total 24) and samples (in total 16) have been randomly taken during the 1st and 30th day of June, 2018. Samples were taken under aseptic conditions, and were representative of the total amount of poultry meat. If the packaging is small in weight, samples with a total weight of $100 \mathrm{~g}$ were taken. Since meat can be contaminated with microorganisms to a greater extent, it is necessary to make appropriate dilutions. The basic dilution is 1:10. Microbiological analyzes were performed on two occasions, in order to assess the microbiological risk that exists in the sale of cut unpackaged chicken meat, swabs were taken during work from surfaces, showcases, clothes and hands of workers and swabs during the repeated procedure. After the results of microbiological analyzes of swabs taken on the first day of sampling were obtained, training of staff working on meat processing and sales was conducted.

The training consisted of presenting the following topics to employees:

- Basics of hygiene in facilities that deal with food (food hazards, ways of food contamination, foodborne illness, personal hygiene of workers, hygiene of surfaces and utensils, pest control).

- Prerequisite programs of the HACCP system and the Law on Food.

- Basics of HACCP system (Principles of HACCP system, system implementation procedure, critical control points and their control).

- Plans for hygiene of protective equipment and personal hygiene.

There were educating on the next main things: Before starting food processing and production, all employees must receive clear and simple instructions on the company's requirements regarding behavior, and in particular on hand washing, as well as the use of work clothes and the reasons for such requirements, and are expected to follow appropriate personal procedures. Hygiene wherever they work.

Three types of media Endo agar, Brilliant green agar and Nutrient agar were used for the work. Preparation of the basis for determining the presence and total number of microorganisms was done according to the reference method of the laboratory. Microbiological analyzes of fresh chicken meat were performed according to the Ordinance on the organization of official controls of products of animal origin intended for human consumption [12] and the Ordinance on amendments to the Ordinance on microbiological criteria for food [13]. Repre- 
sentative samples of chicken meat and offal were chopped up into small pieces which were then chopped in a blender to a diameter of less than the size of a grain of rice. In Erlenmayer flask with glass beads $20 \mathrm{~g}$ of thus prepared sample was added, homogenized and the physiological solution by shaking or vibrating during 15 minutes. Thus, a basic dilution was obtained. Nutrient media Endo agar, Brilliant green agar, Nutrient agar and SS agar were used for the work. The presence of microorganisms in the swabs was examined: coagulase-positive staphylococci, E. coli, Salmonella spp., Sulfite-reducing clostridia, and the total number of aerobic colonies was determined. Since two replicates were performed, the average of the colonies counted was calculated and the results were presented in $\mathrm{CFU} / \mathrm{ml}$ using the formula $\mathrm{CFU}=\mathrm{N} / \mathrm{V}{ }^{*} \mathrm{r}$.

\section{Results and Discussion}

Table 1 presents the results of the number of microorganisms present in swabs sampled on the first and thirtieth day, which were taken from the coats and hands of workers, work surfaces, trays, cooling cabinets and packaging materials from two butchers. The results of the analysis showed that on the first day of sampling, the highest number of aerobic mesophilic bacteria was in hand swabs (butcher A-8.15 $\times 10^{2} \mathrm{CFU} / \mathrm{ml}$, butcher B-17.88 $\times 10^{2} \mathrm{CFU} / \mathrm{ml}$ ) and the lowest in packaging material $\left(0.03 \times 10^{2} \mathrm{CFU} / \mathrm{ml}\right)$. A particularly high number of aerobic mesophilic bacteria $\left(17.88 \times 10^{2} \mathrm{CFU} / \mathrm{ml}\right)$ were found on swabs of workers' hands in Butcher B. The number of Enterobacteriaceae on the first day of sampling was highest on swabs of the cooling cabinet case from butcher A was 1.48 $\mathrm{CFU} / \mathrm{ml}$, and from the hands of workers in butcher $\mathrm{B}$ as mentioned earlier. The presence of Enterobacteriaceae was found on the first day of sampling on swabs packaging material not in a butcher shop.

After the training of the working staff who manipulated with fresh meat, an unannounced re-sampling of swabs on the thirtieth day was done. The results of repeated analyzes showed that the education of workers had an impact on improving the hygienic correctness of swabs and equipment that can be a source of bacteria. Comparing the results of the first and thirtieth sampling day in Table 1 , it can be seen that there was a decrease in the number of aerobic mesophilic bacteria and Enterobacteriaceae for all examined swabs from both butchers. However, it should be noted that swabs from the hands and trays on the thirtieth day of sampling contained the highest number of aerobic mesophilic bacteria in both butchers. Also, the situation is similar with enterobacteria, where on the thirtieth day of sampling on the swabs of workers' hands from both butchers was the largest number of enterobacteria. On the thirtieth day of sampling, the packaging material was still the cleanest, where neither aerobic mesophilic nor enterobacteria were detected. In the end, the performed analyzes showed compliance with the limit values prescribed by the Ordinance. The education of workers, which was focused on personal hygiene and hygienic and sanitary measures in general in the manipulation and sale of fresh chicken meat, proved to be very important and efficient. 
Table 1. Number of microorganisms in the examined swabs.

\begin{tabular}{|c|c|c|c|c|}
\hline \multicolumn{5}{|c|}{ Butcher A } \\
\hline \multirow{2}{*}{ Swabs } & \multicolumn{2}{|c|}{ Aerobic mesophilic bacteria $\left(\times 10^{2} \mathrm{CFU} / \mathrm{ml}\right)$} & \multicolumn{2}{|c|}{ Enterobacteriaceae $(\mathrm{CFU} / \mathrm{ml}$} \\
\hline & 1. day & 30. day & 1. day & 30. day \\
\hline Coat & 2.22 & 0.12 & 0.33 & 0.21 \\
\hline Hands & 8.15 & 0.96 & 1.23 & 0.87 \\
\hline Surface & 0.43 & 0.10 & 1.17 & 0.62 \\
\hline Tray & 3.86 & 0.92 & 1.13 & 0.54 \\
\hline Cooling cabinet & 1.24 & 0.22 & 1.48 & 0.63 \\
\hline Packaging material & 0.05 & 0 & 0 & 0 \\
\hline \multicolumn{5}{|c|}{ Butcher B } \\
\hline Coat & 7.23 & 0.78 & 1.14 & 0.56 \\
\hline Hands & 17.88 & 1.94 & 2.37 & 0.92 \\
\hline Surface & 0.19 & 0.06 & 0.78 & 0.24 \\
\hline Tray & 6.13 & 1.10 & 2.31 & 0.89 \\
\hline Cooling cabinet & 0.86 & 0.11 & 0.93 & 0.31 \\
\hline Packaging material & 0.03 & 0 & 0 & 0 \\
\hline
\end{tabular}

In the examined samples of fresh chicken meat, the number of aerobic mesophilic bacteria during the first sampling was the highest in the samples of the drumstick butcher $\mathrm{A},\left(4.75 \times 10^{3} \mathrm{CFU} / \mathrm{ml}\right)$, slightly less in the samples of the wings $\left(3.78 \times 10^{3} \mathrm{CFU} / \mathrm{ml}\right)$ in same butcher. In same time in butcher $\mathrm{B}$ samples of drumstick $4.13 \times 10^{3} \mathrm{CFU} / \mathrm{ml}$, and wings was $3.82 \times 10^{3} \mathrm{CFU} / \mathrm{ml}$. The presence of Salmolella spp. was confirmed in the samples of the thigh and entrails during the first sampling, while in the other samples it was not determined. In the second sampling, the presence of Salmonella spp. was not found in any of the examined samples. In all examined samples, the number of bacteria was higher in the first compared to the second sampling (Table 2).

As with aerobic mesophilic bacteria, the abundance of Escherichia coli was highest in drumstick samples of A butcher $2.26 \mathrm{CFU} / \mathrm{ml}$, in butcher B was 2.11 $\mathrm{CFU} / \mathrm{ml}$. Offal had the highest number of Escherichia coli in butcher A was 2.3 $\mathrm{CFU} / \mathrm{ml}$, in butcher B was $2.21 \mathrm{CFU} / \mathrm{ml}$. Listeria monocytogenes and Sulfite-reducing clostridia were not found in any of the samples. The results thirtieth day of the analysis showed that Escherichia coli has been found in both butchers in drumsticks A-0.8 CFU/ml, B butcher $0.4 \mathrm{CFU} / \mathrm{ml}$. and offal butcher A $0.6 \mathrm{CFU} / \mathrm{ml}$, butcher B $0.7 \mathrm{CFU} / \mathrm{ml}$, but less than first day (Table 3).

\section{Discussion}

The obtained results show that the most probable sources of pollution are from the product environment, and pollution by manipulation of employees is also 
possible. In the assessment of food safety and viability of poultry meat, microorganisms that cause changes in the sensory properties of meat with their enzymatic activity, as well as pathogenic microorganisms that cause alimentary infections and intoxications, are important. In poultry meat production, there is a change in the composition and number of microflorae between raw material and finished product, where the initial microflora of poultry meat has a significant impact on its sustainability, so the higher the initial contamination, the shorter the sustainability of chicken meat [14] [15].

Table 2. The presence of aerobic mesophilic and Salmonella spp. bacteria in the tested samples.

\begin{tabular}{|c|c|c|c|c|}
\hline \multicolumn{5}{|c|}{ Butcher A } \\
\hline \multirow[t]{2}{*}{ Samples } & \multicolumn{2}{|c|}{$\begin{array}{c}\text { Aerobic mesophilic } \\
\text { bacteria }\left(\times 10^{3} \mathrm{CFU} / \mathrm{ml}\right)\end{array}$} & \multicolumn{2}{|c|}{$\begin{array}{c}\text { Salmonella spp } \\
\text { Presence (+) /absence (-) }\end{array}$} \\
\hline & 1. day & 30. day & 1. day & 30. day \\
\hline Wings & 3.78 & 1.54 & - & - \\
\hline Drumstick & 4.75 & 2.12 & + & - \\
\hline Chests & 2.87 & 1.10 & - & - \\
\hline Offal & 3.67 & 2.10 & + & 0 \\
\hline \multicolumn{5}{|c|}{ Butcher B } \\
\hline Wings & 3.82 & 1.47 & - & - \\
\hline Drumstick & 4.13 & 1.90 & + & - \\
\hline Chests & 2.64 & 0.90 & - & - \\
\hline Offal & 3.64 & 0.9 & + & 0 \\
\hline
\end{tabular}

Table 3. The presence of colonies of Escherichia coli, Listeria monocytogenes and sulfite-reducing clostridia in the tested samples.

\begin{tabular}{|c|c|c|c|c|c|c|}
\hline \multicolumn{7}{|c|}{ Butcher A } \\
\hline \multirow[t]{2}{*}{ Samples } & \multicolumn{2}{|c|}{$\begin{array}{l}\text { Escherichia coli } \\
\qquad(\mathrm{CFU} / \mathrm{ml})\end{array}$} & \multicolumn{2}{|c|}{$\begin{array}{l}\text { Listeria monocytogenes } \\
\text { Presence (+) /absence (-) }\end{array}$} & \multicolumn{2}{|c|}{$\begin{array}{l}\text { Sulfite-reducing clostridia } \\
\text { Presence (+) /absence (-) }\end{array}$} \\
\hline & 1. day & 30. day & 1. day & 30. day & 1. day & 30. day \\
\hline Wings & 1.52 & 0 & - & - & - & - \\
\hline Drumstick & 2.26 & 0.80 & - & - & - & - \\
\hline Chests & 1.13 & 0 & - & - & - & - \\
\hline Offal & 2.3 & 0.6 & - & - & - & - \\
\hline \multicolumn{7}{|c|}{ Butcher B } \\
\hline Wings & 1.70 & 0 & - & - & - & - \\
\hline Drumstick & 2.11 & 0.40 & - & - & - & - \\
\hline Chests & 0.80 & 0 & - & - & - & - \\
\hline Offal & 2.21 & 0.7 & - & - & - & - \\
\hline
\end{tabular}


In order to prevent contamination of meat in the process of production and processing, measures for maintaining personal hygiene of work staff and cleanliness of work clothes must be continuously and rigorously applied, because persons employed in food production are a significant possible source of microbiological and physical hazards [16]. The obtained results indicate that there are hygienic risks in the retail sale of unpackaged fresh chicken meat. These risks should be eliminated or reduced by applying the HACCP system, i.e. precondition programs (GHP, GMP), which is in accordance with Rašeta et al. [17]. Plastic containers or even transport packaging in which meat is displayed in shop windows, should be made of metal, not plastic, because plastic is more difficult to repair, absorbs odors, is a more favorable substrate for the development of microorganisms and is more susceptible to damage, so microbiological risk may also pose a physical risk to chicken meat in the form of plastic debris. Comparing the results of the analysis with other authors, we come to the conclusion that the examined risks are similar or equal to theirs and that the critical points are always related to employee hygiene and hygiene and sanitation of space and equipment.

As expected in the repeated analysis of samples of fresh poultry meat and hand swabs and containers in which the meat is stored until sale showed better results. After control of the same samples in a reanalysis of the situation of health safety of chicken meat is much improved. However, it can still be said that product controls should still be performed in retail outlets until sufficiently reliable results of microbiological analyzes of products are achieved.

Based on the analysis of swabs taken from workers' hands, clothes, and various surfaces during the first sampling, it can be said that good hygiene practice was not followed. This is a sufficient indicator that proper care must be taken to properly carry out cleaning, washing and disinfection, especially on warmer days, because the elevated temperature is conducive to faster growth and reproduction of microorganisms. The presence of identified bacteria during the test indicates that there is a health risk for consumers and it is necessary to determine corrective measures as part of self-control procedures within outlets that would eliminate this risk or reduce it to an acceptable level. This agrees with the findings of [18] and [19]. Hand hygiene of workers who comes into contact with food in production and trade is of special importance. Pathogenic microorganisms can be transmitted to food by workers 'hands, as well as from surfaces with which food and workers' hands come into contact.

After comparing the obtained research results with the available literature, we come to the conclusion that in these two sales facilities in Zenica after the first control, more attention was paid to good hygiene practice. In the end, we concluded that the most common causes of contamination of fresh chicken meat are plastic lodges, meat bags as well as workers' hands, because after the first sampling, the results showed the presence of microorganisms on them. Food contact surfaces must be cleaned and disinfected several times a day. According to [18] 
and [3], cleaning of other areas and areas can be carried out daily, weekly or annually, depending on the level of pollution, but often enough to avoid any danger of contamination.

\section{Conclusions}

- Based on the swabs taken of workers' hands, clothes, working surfaces during the first sampling, we can conclude that good hygiene practice in butchers was not followed.

- This is a sufficient indicator that proper care must be taken to properly carry out cleaning, washing and disinfection, especially on warmer days, because the elevated temperature is conducive to faster growth and reproduction of microorganisms.

- The number of grown colonies in the first analysis of the taken swabs was not in accordance with the norms of microbiological purity, ie they were positive for aerobic mesophilic bacteria, and the swabs were characterized as microbiologically defective.

- The largest number of Enterobacteria was detected in swabs taken from workers' hands, and slightly less in swabs from work clothes during both samplings.

- Based on the results of the analysis of swabs from the hands of workers, clothing, various surfaces, objects after the training, a significant shift in good hygiene practice was confirmed.

- We can conclude that there is a possibility that the meat is contaminated during storage, display and sale in retail outlets, so it is recommended that chicken meat is sold in its original packaging.

\section{Conflicts of Interest}

The authors declare that there are no conflicts of interest regarding the publication of this paper and we agree with Prof. Enver Karahmet about publication of this work.

\section{References}

[1] Pravilnik o Tržnim Standardima za Meso Živine Sl. Glasnik BiH br. 74/14.

[2] Sučić, R., Cvrtila, Ž., Njari, B. and Kozačinski, L. (2010) Senzorne, Kemijske i Mikrobiološke Promjene u Zamrznutom Mesu Peradi. Meso, XII, 348-357.

[3] Karahmet, E., Toroman, A. and Hamidović, S. (2017) Higijena i Sanitacija Pogona u Prehrambenoj Industriji, Sarajevo, BiH.

[4] za Hranu, H.A. (2011) Znanstveno Mišljenje o Kvaliteti Zamrznutog Mesa Peradi (Zahtjev HAH-Z-2011-1).

[5] Mulder, R.W.A.W. (1999) Hygiene during Transport, Slaughter and Processing. In: Richardson, R.I. and Mead, G.C., Eds., Poultry Meat Science, Vol. 25, CABI Publishing, Wallingford, 277-285.

[6] Fries, R. (2002) Reducing Salmonella Transfer during Industrial Poultry Meat Production. World s Poultry Science Journal, 58, 527-540. 
https://doi.org/10.1079/WPS20020038

[7] Pravilnik o Higijeni Hrane (Sl. Glasnik BiH br. 04/13).

[8] Pravilnik o Higijeni Hrane Životinjskog Porijekla (Sl. Glasnik BiH 103/12).

[9] Pravilniku o Vršenju Mikrobioloških Analiza (Sl. List BiH br. 11/13).

[10] Operta Sabina (2016) Tehnologija Proizvoda od Mesa Peradi. Poljoprivredno Prehrambeni Fakultet Sarajevo

[11] Perez-Rodriguez, F., Castro, R., Posada Izquiero, G.D., Valero, A., Carrasco, E., Garcia Gimeno, R.M. and Zurera, G. (2010) Evaluation of Hygiene Practices and Microbiological Quality of Cooked Meat Products during Slicing and Handling in Retail. Meat Science, 86, 479-485. https://doi.org/10.1016/j.meatsci.2010.05.038

[12] Pravilnik o Organizaciji Službenih Kontrola Proizvoda Životinjskog Porijekla Namijenjenih Ishrani Ljudi (Službeni Glasnik, BiH br. 103/12).

[13] Pravilnik o Izmjenama i Dopunama Pravilnika Mikrobiološkim Kriterijima za Hranu (Službeni Glasnik BiH, broj 79/16).

[14] Živković, J., Njari, B. and Kozačinski, L. (1994) Kakvoća i Higijenska Ispravnost Mesa u Funkciji Unapređenja Peradarstva. Peradarski dani 94. Trakošćan 5-7 listopada. Zbornik, 58-67.

[15] Kozačinski, Z. (2003) Ocjena Održivosti Svježega ga Pilećeg Mesa na Domaćem Tržištu. Stručni Rad. Veterinarski Fakultet Sveučilišta u Zagrebu. Zagreb.

[16] Beganović, A.H. (1975) Mikrobiologija Mesa i Mesnih Prerađevina, Univerzitet u Sarajevu.

[17] Rašeta, M., Bunčić, O., Matekalo-Savrek, V., Vranić, V., Branković-Lazić, I. and Spirić, D. (2012) Higijenski Rizici pri Prometu Neupakovanog Rasečenog Pilećeg Mesa u Maloprodaji. Tehnologija Mesa, 53, 121-126. https://doi.org/10.5937/tehmesa1202121R

[18] Baroš, K., Hegedušić, P., Karačić, T. and Premzl, D. (2010) Vodič za dobru Higijensku Praksu Primjenu Načel HACCP-a u Industriji Mesa, I dio Higijenska Praksa, HGK, Sektor za Poljoprivredu, Prehrambenu ind ustriju i Šumarstvo, Zagreb, Hrvatska.

[19] Kozačinski, Z. and Hadžiosmanović, M. (2003) Održivost Svježeg Pilećeg Mesa. Meso, br. 2. Zagreb. 